\title{
Seasonal contribution of terrestrial organic matter and biological oxygen demand to the Baltic Sea from three contrasting river catchments
}

\author{
H. E. Reader ${ }^{1}$, C. A. Stedmon ${ }^{2}$, and E. S. Kritzberg ${ }^{1}$ \\ ${ }^{1}$ Department of Biology/Aquatic Ecology, Lund University, Sölvegatan 37, 22362 Lund, Sweden \\ ${ }^{2}$ National Institute for Aquatic Resources, Technical University of Denmark, Kavalergården 6, 2920 Charlottenlund, Denmark \\ Correspondence to: H. E. Reader (heather.reader@biol.lu.se)
}

Received: 21 December 2013 - Published in Biogeosciences Discuss.: 22 January 2014

Revised: 19 April 2014 - Accepted: 1 May 2014 - Published: 27 June 2014

\begin{abstract}
To examine the potential influence of terrestrially derived DOM on the Baltic Sea, a year-long study of dissolved organic matter (DOM) was performed in three river catchments in Sweden. One catchment drains into the Bothnian Sea, while two southern catchments drain into the Baltic proper. Dissolved organic carbon (DOC) concentrations were positively correlated with discharge from forested catchments over the year. While the overall concentrations of DOC were several times higher in the southern two catchments, higher discharge in the northern catchment resulted in the annual loadings of DOC being on the same order of magnitude for all three catchments. Biological oxygen demand (BOD) was used as a proxy for the lability of carbon in the system. The range of BOD values was similar for all three catchments, however, the ratio of BOD to DOC (an indication of the labile fraction) in Ume river was four times higher than in the southern two catchments. Total annual BOD loading to the Baltic Sea was twice as high in the northern catchment than in the two southern catchments. Lower winter temperatures and preservation of organic matter in the northern catchment combined with an intense spring flood help to explain the higher concentrations of labile carbon in the northern catchment. Lower lability of DOM as well as higher colour in the southern catchments suggest that wetlands (i.e. peat bogs) may be the dominant source of DOM in these catchments, particularly in periods of low flow. With climate change expected to increase precipitation events and temperatures across the region, the supply and quality of DOM delivered to the Baltic Sea can also be expected to change. Our
\end{abstract}

results indicate that DOM supply to the Baltic Sea from boreal rivers will be more stable throughout the year, and potentially have a lower bioavailability.

\section{Introduction}

In the boreal regions freshwater dissolved organic matter (DOM) concentrations are increasing. This widespread phenomenon of increasing dissolved organic carbon (DOC) as well as water colour, or chromophoric dissolved organic matter (CDOM), is attributed to higher concentrations of terrestrially derived DOM and has been observed in Scandinavia (De Wit et al., 2007; Erlandsson et al., 2008), Canada (Monteith et al., 2007) and the UK (Evans, 2005) as well as other countries (Hruška et al., 2009). Increasing DOM and water colour have profound effects on the ecosystem, changing the aquatic light environment and increasing the supply of allochthonous substrates for the planktonic communities. Several factors have been suggested as drivers of this increasing organic matter trend, from decreasing acidification (Evans et al., 2012; Monteith et al., 2007) changing hydrology and warming climates (Evans, 2005) to increasing ionic strength in soils (Hruška et al., 2009) and changes in land use (Garnett et al., 2000). The specific processes behind these trends are likely to at least partially vary regionally (Oni et al., 2013).

A large amount of this terrestrially derived DOM is actively cycled in the freshwater systems; however, despite this 
active cycling, a significant fraction of this DOM, up to $50 \%$ of the input or $\sim 0.9 \mathrm{Pg} \mathrm{C}_{\text {year }}{ }^{-1}$ (Cole et al., 2007; Tranvik et al., 2009; Battin et al., 2009), is subsequently transported to the coastal ocean and there continues to be degraded by marine microbial communities. While terrestrial DOM has historically been considered as refractory to aquatic microbes (Nagata, 2008), it is now recognised that it consists of a continuum of reactive components (Nagata, 2008; Koehler et al., 2012). In the 1970s it was established that DOM could play a significant role in fuelling microbial food webs in the coastal ocean (Pomeroy, 1974), and more recently, it has been shown that the zooplankton community is also capable of using allochthonous carbon sources as effective energy sources (Rolff and Elmgren, 2000). Microbial degradation of terrestrially derived DOM has been suggested as a compounding factor in the Gulf of Mexico dead zone, increasing hypoxia in the coastal zone contributing to elevated oxygen consumption and eventual depletion (Dagg et al., 2008). This process is also likely to occur in other hypoxic basins such as the Baltic Sea, where increasing terrestrial DOM input into the system may exacerbate of hypoxic conditions, particularly in the northern regions, where increasing freshwater input has already been shown to be driving an ecosystem shift from net autotrophy to net heterotrophy (Wikner and Andersson, 2012).

The reactivity of DOM is controlled by its chemical characteristics, or "quality". The quality of DOM is not readily defined but there are several indicators that are often used to describe DOM. The slope of the chromophoric DOM (i.e. CDOM) absorption spectrum can be used as an indicator of carbon quality, specifically, the slope of the spectrum in the ultraviolet (i.e. $275-295 \mathrm{~nm}$ ) has been shown to be an indicator of the molecular size of DOM (Helms et al., 2008). This can be a useful indicator of DOM quality as larger molecules are often thought to be more biologically reactive (Amon and Benner, 1996, 1994). In addition, the carbon specific ultraviolet absorption $\left(\mathrm{SUVA}_{254}\right)$ is an indicator of the aromatic character of the DOM, with a higher $\mathrm{SUVA}_{254}$ value indicating that the DOM has a higher aromatic content (Weishaar et al., 2003), and is likely to be less biologically available (Perdue, 1998). The drawback of these quality indicators is that they characterise only a fraction of the DOM pool. To assess the actual effect of DOM on oxygen conditions, microbial assays such as simple biological oxygen demand (BOD) incubations can be used to determine the bulk reactivity of the DOM with respect to the microbial community. While there is a range of efficiencies with which the microbial community can access DOM (i.e. respiratory quotient RQ; Berggren et al., 2012), for the most part these boreal freshwater RQs fall within a relatively small range (0.5-2) and as such BOD can be used as an effective proxy for the biological reactivity or lability of the DOM (Miller et al., 2002; Asmala et al., 2013).

An extensive system of water quality and water flow monitoring exists in Sweden, making it possible to observe how flow (Erlandsson et al., 2008) and organic matter quality indicators (Kritzberg and Ekström, 2012) have changed over time. However, dynamics of biological reactivity require different assessments, such as BOD, which are more timeconsuming and therefore rarely incorporated into long-term monitoring programs. In this paper we present a year-long study of the DOM in three Swedish rivers flowing into the Baltic Sea. The Baltic Sea is a semi-enclosed basin which is heavily influenced by runoff from the surrounding terrestrial regions. In addition to having a freshening effect on the Baltic, the many rivers flowing into the Baltic Sea input a large amount of nutrients, making the Baltic Sea the world's largest hypoxic basin, with permanent anoxia in deep bottom waters, as well as periodic hypoxia shallower coastal regions (Conley et al., 2011). The rivers flowing into the Baltic also supply organic matter and as a consequence up to $86 \%$ of the DOM in the Baltic Sea is thought to be terrestrially derived (Alling et al., 2009; Deutsch et al., 2012). The reactivity of this terrestrial DOM is poorly understood and as a result little is known about its contribution to hypoxic conditions in the Baltic Sea. The aim of the study is to examine DOM fluxes from rivers to the Baltic Sea, and how loadings of reactive DOM vary spatially and seasonally. We hypothesize that DOM concentrations and reactivity will vary seasonally with the discharge of the rivers. We assess this in three contrasting Swedish rivers, occupying distinct climatic zones.

\section{Methods}

\subsection{Sampling and measurements}

A year-long study of riverine organic matter was undertaken at 3 catchments in Sweden (Fig. 1, Table 1). The Ume river catchment is covered by $7 \%$ peatlands and $62 \%$ forest, and occupies a subarctic zone, with winter temperatures below freezing. Ume catchment can be roughly divided into subcatchments, upper Ume, and Vindeln. The sampling site for Ume (Fig. 1, Table 1) is downstream of the confluence of the two major subcatchments. Upper Ume is highly regulated with several hydro dams along its length, while Vindeln is unregulated and more forested. Ume river is the most northern catchment and flows into the Bothnian Sea. The Emån and Lyckeby rivers occupy a more temperate climate zone with mean winter temperatures around $0{ }^{\circ} \mathrm{C}$, and 69 and $72 \%$ forest cover, respectively, as well as lower peatland cover, 2 and $1 \%$, respectively. Both Emån and Lyckeby rivers drain into the Baltic proper.

Flow data for the sampling period was obtained from the Swedish Meteorological and Hydrological Institute's Vattenweb (SMHI, http://vattenweb.smhi.se/station/), who operate flow metres at the points of sampling. Flow data for Krycklan catchment (a low altitude subcatchment of Vindeln catchment) was obtained from the Krycklan Catchment Study (Laudon et al., 2013). Catchment areas and 


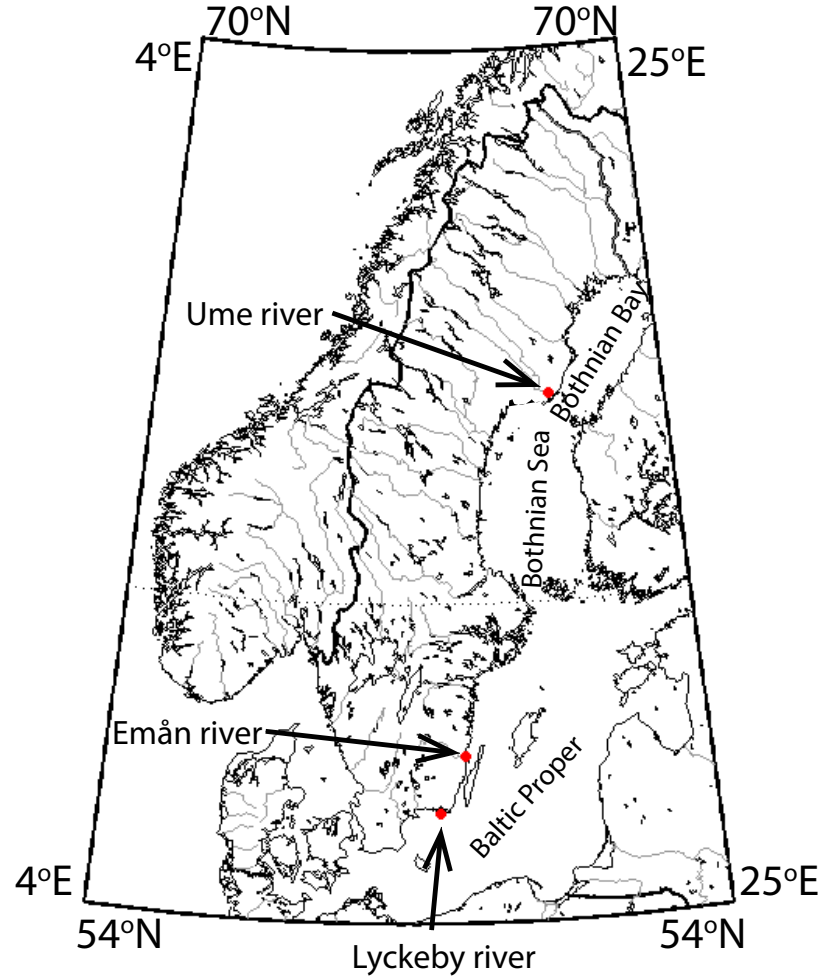

Figure 1. Map of catchments locations. From north to south: Ume river, Emån river, Lyckeby river.

land cover data were obtained from the Swedish Statistical Board (http://www.scb.se) and land use classifications according to the GSD Survey map (open GIS database; http://www.lantmateriet.se). Climate data was obtained from SMHI (http://www.smhi.se/klimatdata).

Monthly samples of river water were collected in $2 \mathrm{~L}$ polycarbonate bottles (Nalgene) and were stored on ice in the dark until returned to the laboratory $(<8 \mathrm{~h})$. Upon return to the laboratory, samples for DOC and CDOM measurements were pre-filtered using ashed $\left(450^{\circ} \mathrm{C}, 4 \mathrm{~h}\right) \mathrm{GF} / \mathrm{F}$ filters (Whatman), and then filtered through $0.2 \mu \mathrm{m}$ polycarbonate filters (Millipore). DOC was measured on a Shimadzu TOC $\mathrm{V}-\mathrm{CPN}$ in TC mode. The instrument was calibrated daily with a $\mathrm{Na}_{2} \mathrm{CO}_{3}$ for IC analysis and potassium hydrogen phthalate for TC analysis. CDOM absorbance was measured in a $1 \mathrm{~cm}$ quartz cell on a Beckman Coulter D800 from 200 to $800 \mathrm{~nm}$.

Biodegradable dissolved organic carbon was assessed as two-week biological oxygen demand (BOD) measurements. Samples were filtered through ashed GF/F filters directly into $60 \mathrm{~mL}$ Winkler bottles which were sealed without headspace. The filtration was done to remove larger organisms and their contribution to respiration, as well as to remove particulate and detritus which may act as additional substrate for microbial degradation. Three bottles were fixed immediately with Winkler reagents, and three more were incubated in the

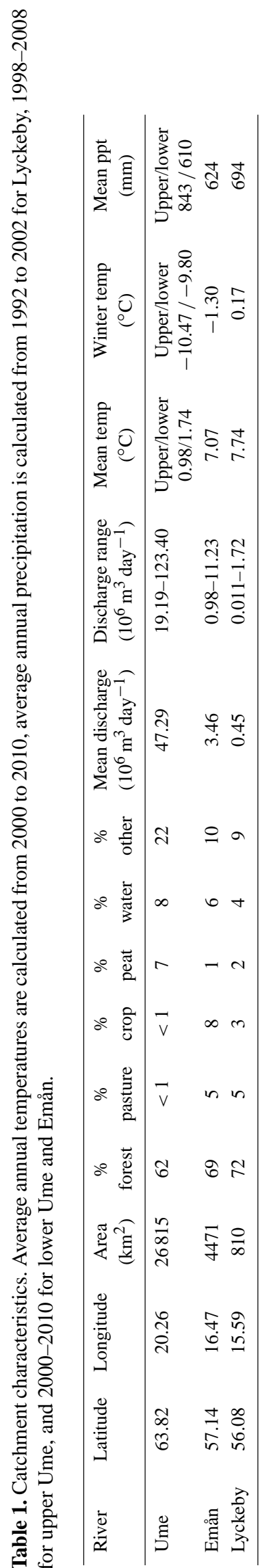

Biogeosciences, 11, 3409-3419, 2014 
dark at $20.5^{\circ} \mathrm{C}$ for two weeks. The two-week incubation period was chosen to give the bacterial community time to reestablish from the filtration, as well as be short enough to minimise any contribution to oxygen consumption from nitrification. The incubation was performed in the dark to eliminate further complications from photochemical processes. Photochemistry is known to both produce and destroy biologically labile DOM and competition between microbes and photochemical processes could complicate the interpretation of results (Reader and Miller, 2014). Samples were then titrated using a Mettler Toledo titrator according to the Winkler method.

\subsection{Calculations}

CDOM was measured on a Beckman Coulter DU-800 spectrophotometer in a $1 \mathrm{~cm}$ quartz cuvette using milli-Q water as a reference and a blank. The absorption coefficient was calculated according to the equation

$a(\lambda)=A^{*} 2.303 / l$,

where $A$ is the measured absorbance, $l$ is the path length of the cell in metres and 2.303 converts from decadal units to Naperian units. Spectral slope was estimated using a nonlinear regression routine in MATLAB, across $275-295 \mathrm{~nm}$

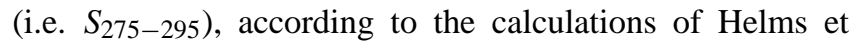
al. (2008) and was used as an indicator of the relative molecular size of the DOM. Specific ultraviolet absorbance (SUVA, $\mathrm{m}^{2} \mathrm{~g}^{-1} \mathrm{C}$ ), was calculated as the ratio between decadal absorbance at $254 \mathrm{~nm}\left(\mathrm{~m}^{-1}\right)$ and total organic carbon $\left(\mathrm{mg} \mathrm{L}^{-1}\right.$; Weishaar et al., 2003). It is used as an indicator of the aromatic content of the DOC.

Monthly loadings were calculated by summing the total flow for the month and multiplying by the monthly measurements of DOC, CDOM, and BOD. Annual loadings are the sums of the 12 monthly loadings. To account for months where there is missing data, a linear extrapolation between the two bordering months was used to obtain a DOM value, and a monthly loading was obtained from that. This data was used solely for the calculation of the yearly loading and not the assessment of yearly patterns. An alternative method of determining flow relationships with carbon variables (i.e. Q$\mathrm{C}$ relationships) was attempted. This method is often successfully employed in smaller catchments (Strohmeier et al., 2013; Jollymore et al., 2012). When a valid Q-C relationship was obtained, the difference between loadings obtained using the monthly average method and the Q-C method was between $-3.5 \%$ and $+3.8 \%$. However, valid Q-C relationships were not found for all rivers and all variables. Because the differences between the methods were small, the monthly average method was used for all rivers and variables to ensure consistency. Pearson correlations were used to determine covariance of different organic matter characteristics and flow. All calculations were performed in Matlab.

\section{Results}

\subsection{Hydrographs}

Ume catchment is the largest of the three study sites, and the flow was an order of magnitude higher than in either of the two southern catchments. The hydrograph (grey bars, Figs. 2 and 3) has two distinct peaks, one in June during the spring flood, and the other in October. In Emån catchment, the hydrograph also shows two peaks. The first was in January during the winter peak precipitation season and the second in July during an anomalous precipitation event, which caused widespread flooding throughout the catchment. In Lyckeby, flow peaked in the winter months, during the normal period of high precipitation. Though the two southern catchments are relatively close to each other (separated by $\sim 140 \mathrm{~km}$ ), the summer months in Lyckeby did not experience the same anomalous precipitation and instead were characterised by low precipitation and consequently low flow.

\subsection{DOC and CDOM}

Dissolved organic carbon (DOC) was similar in the two southern rivers (Table 2), while the mean concentration of DOC in Ume river was lower (one-way ANOVA, $p<$ $0.0001, F=89.23$ ). CDOM (measured as $a_{375}$ ) correlated strongly with DOC in all three rivers (Table 3). Monthly variability of DOC and CDOM showed two distinct peaks in Ume river, one the month before the spring flood, and another during autumn peak flow in October. While the first peak in carbon appeared before the spring flood, it coincided with the spring flood in the lower forested parts of the catchment. DOC was correlated not with flow on Ume river after the confluence of the two subcatchments, but rather with flow in the forested lower catchment (Table 3). The existence of dams on the upper Ume river part of the catchment obscures this relationship by changing the flow after the confluence of the two parts of the catchment. Despite the influence of these dams on the flow on the river, widespread oligotrophication of dammed water in Sweden means that these dams are not likely to be driving DOC concentrations (for example from autochthonous production) (Rydin et al., 2008). In Emån river, carbon characteristics (i.e. DOC and CDOM) were driven by flow in the spring and summer months, especially during the July flooding event, but concentrations of DOC and CDOM were steady throughout the winter peak flow (December-February, Fig. 2). However, overall DOC was strongly correlated with flow in this river (Table 3). In Lyckeby river, flow was extremely low over the summer months, but both DOC and CDOM decreased slowly over the low flow period, reaching their minimum in October and November, before rising again over the winter months (Fig. 2). Because of this, while DOC was still correlated with flow in Lyckeby catchment, it was less significant than in the other two catchments (Table 3 ). 

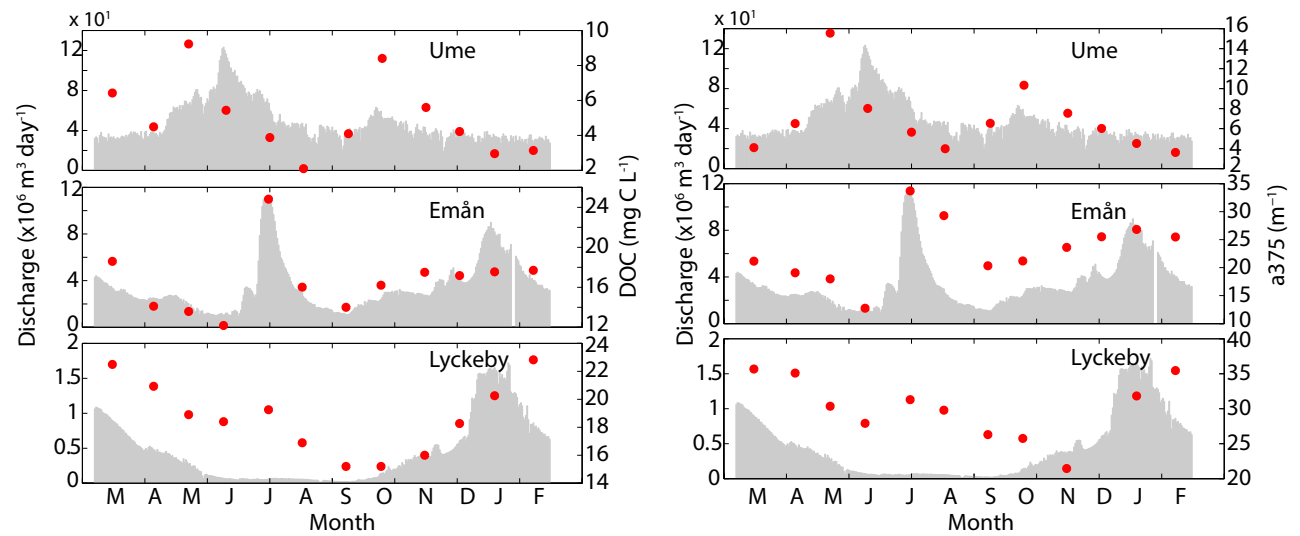

Figure 2. Dissolved organic carbon (left) and CDOM ( $a_{375}$, right) for the three catchments. Red dots are organic matter characteristics, grey bars represent the daily flow on each river at the point of sampling.
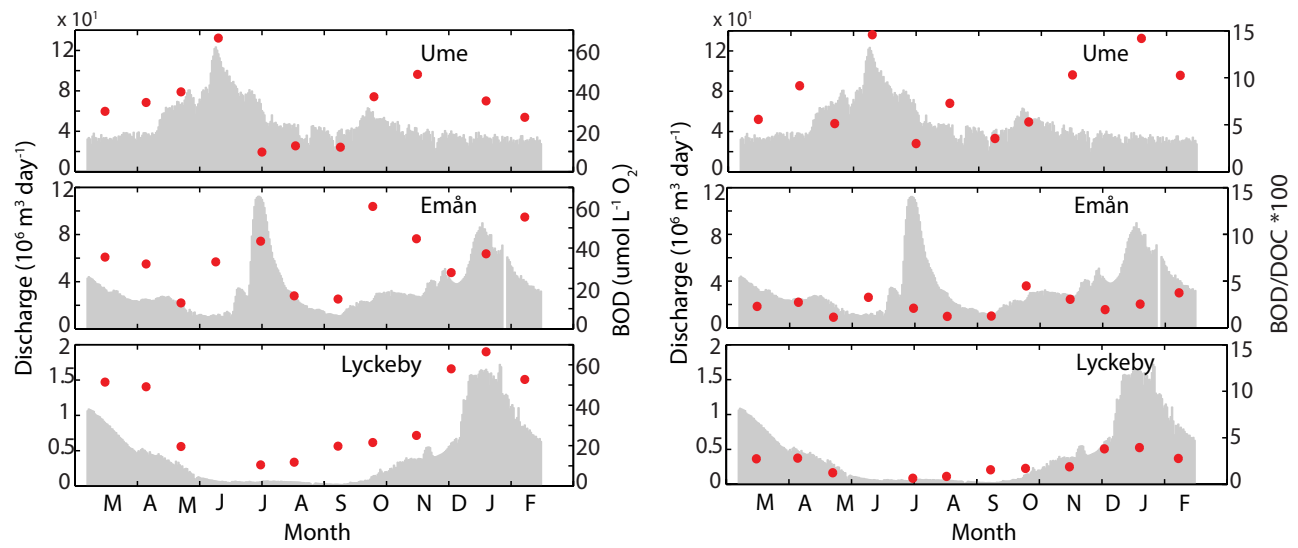

Figure 3. Biological oxygen demand (left) and percent of total dissolved organic carbon that is biologically reactive (i.e. BOD/DOC ratio $\cdot 100$, assuming an respiratory quotient of one) for the three rivers. Red dots are organic matter characteristics, grey bars represent the daily flow on each river at the point of sampling.

\subsection{DOM quality indicators}

Quality characteristics of the organic matter (spectral slope, SUVA $_{254}$ ) can be found in Table 2. Neither spectral slope nor SUVA $_{254}$ held any explanatory value when considering DOC or BOD variability. The total range of BOD was similar across the three catchments (Table 2, Fig. 3a) with values ranging between 10 and $70 \mu \mathrm{mol} \mathrm{L}{ }^{-1} \mathrm{O}_{2}$. In Lyckeby, BOD was significantly correlated to flow, while in the other two catchments it was not (Table 3). However, BOD was clearly higher during the spring flood in Ume (Fig. 3a). BOD was not correlated to DOC in either Ume or Emån, but was weakly correlated in Lyckeby (Table 3). Despite the fact that the absolute values of BOD were in the same range for all three catchments (one-way ANOVA, $p=0.9046, F=0.1$ ), the fraction of DOC that is biodegradable (i.e. BOD to DOC ratio, $\mathrm{BOD} / \mathrm{DOC}$ ) is $\sim 4$ times higher in Ume river, than in the southern two rivers (Table 2, Fig. 3a; one-way ANOVA, $p<$ $0.0001, F=20.3$ ). In the two southern rivers, BOD/DOC over the year was consistent and low (less than 5\%, Fig. 3b), suggesting that the DOC in these rivers is largely refractory on this timescale. In Ume river the fraction of DOC that was biodegradable over the year was much more variable over the year, at times being as high as $15 \%$ during the spring flood in June, as well as in January.

\subsection{DOM loadings}

To assess the potential effect that the delivery of organic matter has on the Baltic Sea ecosystem, loadings of carbon indicators were calculated. The total annual carbon yield was similar between the catchments (Table 4), with the lowest value in Ume catchment $\left(3.43 \mathrm{~g} \mathrm{C} \mathrm{m}^{-2}\right.$ year $\left.^{-1}\right)$ and highest in Emån catchment $\left(5.04 \mathrm{~g} \mathrm{C} \mathrm{m}^{-2}\right.$ year $\left.^{-1}\right)$. CDOM yields are relatively high and follow the same pattern with 4.86 and 7.08 year $^{-1}$ for Ume and Emån catchments, respectively. Annual areal loadings of BOD show a different pattern, with similar values for Emån and Lyckeby catchments (10.39 and $10.29 \mathrm{mmol} \mathrm{O}_{2} \mathrm{~m}^{-2}$ year $^{-1}$, respectively), while 
Table 2. Organic matter characteristics for the three catchments.

\begin{tabular}{|c|c|c|c|c|c|c|c|c|c|c|}
\hline \multirow[t]{2}{*}{ River } & \multicolumn{2}{|c|}{ DOC } & \multicolumn{2}{|c|}{$S_{(275-295)}$} & \multicolumn{2}{|c|}{$\mathrm{SUVA}_{254}$} & \multicolumn{4}{|c|}{ BOD } \\
\hline & $\begin{array}{l}\text { (mean } \\
\mathrm{mg} \mathrm{L}^{-1} \text { ) }\end{array}$ & $\begin{array}{l}\text { (range } \\
\mathrm{mg} \mathrm{L}^{-1} \text { ) }\end{array}$ & $\begin{array}{l}\text { mean } \\
\left(\mu \mathrm{m}^{-1}\right)\end{array}$ & $\begin{array}{l}\text { range } \\
\left(\mu \mathrm{m}^{-1}\right)\end{array}$ & $\begin{array}{l}\text { mean } \\
\left(\mathrm{m}^{2} \mathrm{~g}^{-1} \mathrm{C}\right)\end{array}$ & $\begin{array}{l}\text { range } \\
\left(\mathrm{m}^{2} \mathrm{~g}^{-1} \mathrm{C}\right)\end{array}$ & $\begin{array}{l}\text { mean } \\
\left(\mu \mathrm{mol} \mathrm{L}^{-1} \mathrm{O}_{2}\right)\end{array}$ & $\begin{array}{l}\text { range } \\
\left(\mu \mathrm{mol} \mathrm{L}-1 \mathrm{O}_{2}\right)\end{array}$ & $\begin{array}{l}\text { mean }(\% \text { of } \\
\text { total DOC) }\end{array}$ & $\begin{array}{l}\text { range (\% of } \\
\text { total DOC) }\end{array}$ \\
\hline Ume & 5.00 & $2.10-9.23$ & 14.61 & $13.35-16.43$ & 3.59 & $1.72-5.38$ & 31.9 & $9.7-66.1$ & 8.0 & $3.0-14.6$ \\
\hline Emån & 16.62 & $12.19-24.82$ & 14.48 & $13.65-16.40$ & 3.58 & $2.96-4.51$ & 34.5 & $12.8-60.6$ & 2.5 & $1.1-4.5$ \\
\hline Lyckeby & 18.72 & $15.20-22.82$ & 13.71 & $12.97-14.26$ & 3.94 & $3.47-4.31$ & 35.1 & $10.5-66.5$ & 2.2 & $0.7-3.9$ \\
\hline
\end{tabular}

Table 3. Correlation statistics for various catchment characteristics.

\begin{tabular}{lcccccc}
\hline Relationship & \multicolumn{2}{c}{ Ume } & \multicolumn{2}{c}{ Emån } & \multicolumn{2}{c}{ Lyckeby } \\
& $r$ & $p$ & $r$ & $p$ & $r$ & $p$ \\
\hline DOC - $a_{375}$ & 0.85 & $<0.001$ & 0.84 & $<0.001$ & 0.90 & $<0.001$ \\
DOC - flow & 0.31 & 0.33 & 0.86 & $<0.001$ & 0.62 & $<0.05$ \\
BOD - flow & 0.57 & 0.07 & 0.29 & 0.36 & 0.88 & $<0.001$ \\
BOD - DOC & 0.46 & 0.16 & 0.43 & 0.16 & 0.64 & $<0.05$ \\
DOC - Krycklan flow & 0.71 & $<0.05$ & N/A & N/A & N/A & N/A \\
BOD - Krycklan flow & 0.30 & 0.43 & N/A & N/A & N/A & N/A \\
\hline
\end{tabular}

Table 4. Areal annual loadings of organic matter for the three catchments.

\begin{tabular}{llll}
\hline River & $\begin{array}{l}\text { DOC } \\
\left(\mathrm{g} \mathrm{C} \mathrm{m}^{-2} \text { year }^{-1}\right)\end{array}$ & $\begin{array}{l}\text { CDOM } \\
\left(a_{375}\right)\left(\mathrm{year}^{-1}\right)\end{array}$ & $\begin{array}{l}\text { BOD } \\
\left(\mathrm{mmol} \mathrm{O}_{2} \mathrm{~m}^{-2} \text { year }^{-1}\right)\end{array}$ \\
\hline Ume & 3.43 & 4.86 & 22.79 \\
Emån & 5.04 & 7.08 & 10.39 \\
Lyckeby & 4.08 & 6.37 & 10.29 \\
\hline
\end{tabular}

the total loading of BOD in Ume catchment is double that of the southern catchments at $22.79 \mathrm{mmol} \mathrm{O}_{2} \mathrm{~m}^{-2}$ year $^{-1}$.

Monthly loadings of DOC (Fig. 4a) show that carbon loading is driven by flow for all of the rivers, as expected from the variability of DOC concentrations over the year, and the correlation between DOC and flow (Table 3). While the flow regime is clearly important also to the monthly loadings of BOD, the coupling to the hydrograph is less tight than for DOC (Fig. 4b). The spring flood peak in June in Ume delivers over $30 \%$ of the year's total BOD to the Baltic from that catchment. In Lyckeby river catchment, BOD monthly loadings are directly driven by flow (Figs. 3, 4, and Table 3), because of the extremely low flow through the summer months. In Emån river, catchment delivery of BOD to the Baltic has a more flattened pattern over the year, despite the high variability in flow, with no month delivering more than $20 \%$ of the total annual loading of BOD to the Baltic.

\section{Discussion}

The Baltic Sea is a strongly terrestrially influenced system and the riverine delivery of reactive DOM has the potential to compound the already oxygen stressed conditions present in the region. The consumption of oxygen by microbial DOM degradation can add to the oxygen consumption driven by phytoplankton decay. While the delivery of DOM to the Baltic from surrounding landmasses has been investigated previously (Deutsch et al., 2012; Weyhenmeyer et al., 2012), the loadings of reactive material have not been explicitly studied before. Swedish rivers deliver DOM year round to the Baltic, however the reactivity of that DOM is not necessarily the same through the year and it is the delivery of reactive material that has the primary impact on the marine environment. Thus, investigating the loadings of reactive material to the Baltic Sea is an informative way to understand the impact of riverine DOM on the Baltic Sea ecosystem. The southern two catchments have similar DOC and BOD areal annual loadings to the Baltic Sea, but have different monthly patterns of loadings, due to differing flow hydrographs and precipitation in the catchments, particularly in summer. While Lyckeby catchment experienced little rainfall and low flow in the summer, Emån catchment experienced high summer precipitation leading to flooding throughout the catchment in July resulting in a more even delivery of reactive material throughout the year. The northern catchment, with its colder winters, experiences a strong spring flood, and DOC concentrations correlate with flow in the lower forested parts of the catchment, while BOD concentrations correlate better with flow on the entire catchment. Additionally, the overall areal annual loading of BOD is twice as high in the northern catchment than in the southern catchments. Higher loading of reactive material to the Bothnian Sea suggests that this region is more influenced by the terrestrial system than the more southern Baltic proper. 

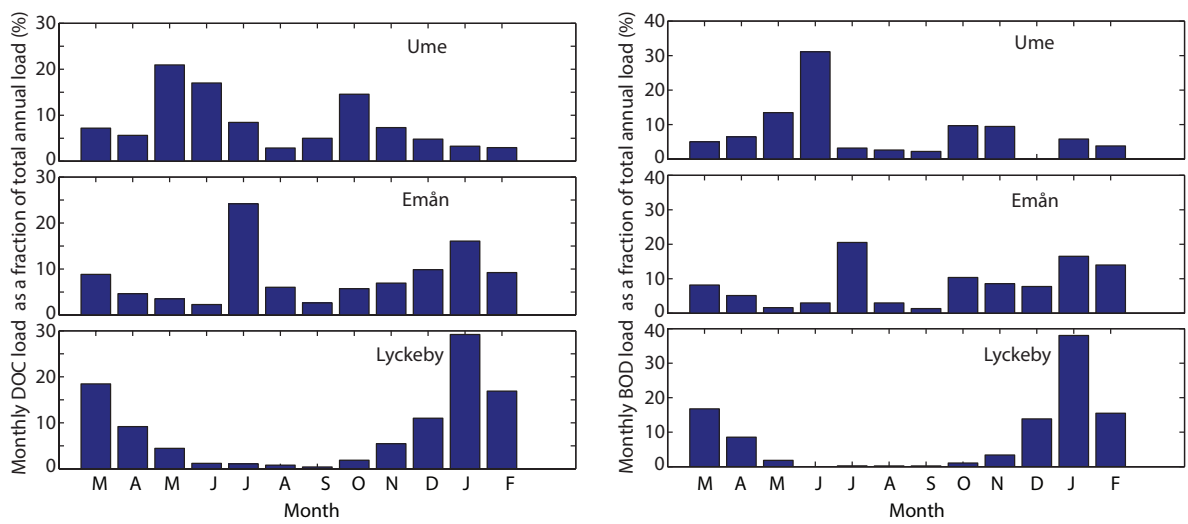

Figure 4. Mean monthly loadings of dissolved organic carbon and biological oxygen demand, represented as a percent of the total annual loading for each river.

\subsection{Differences in reactivity between rivers and over seasons}

In the southern two rivers, the overall bioavailability, as a fraction of the total DOC, is low, with only $\sim 2 \%$ of the DOC being bioavailable on this timescale in any given month. The moderate annual temperatures in these two catchments can allow for substantial microbial processing along the transit to the river mouth, leading to low bioavailability at the river mouth sampling point. In a similar study of three rivers in Finland, Asmala et al. (2013) also found relatively low bioavailability for a similar forested catchment (mean of $7.91 \%$ ), with a lack of seasonality much like in Emån and Lyckeby. During the dry summer months in Lyckeby catchment, high residual DOC and CDOM concentrations in the river despite low flow are suggestive of wetland draining being the major source of water in the river, in those periods rather than overland flow and flow through superficial soil layers that are more likely during precipitation events (Bishop et al., 1993).

The differences between these southern rivers and the northern river, Ume river, are clear from the annual areal loadings of DOM (Table 3). While DOC areal loadings are similar for all three rivers, the loading of BOD is twice as high in the northern river as in the southern two rivers. This is despite the fact that the DOC concentrations in Ume river are considerably lower, and reflects the higher range of BOD/DOC; i.e. the bioavailability of the DOC.

The mean annual temperature $\left(\sim 1^{\circ} \mathrm{C}\right.$, Table 1$)$, and significantly, the mean winter temperature $\left(-10^{\circ} \mathrm{C}\right)$ in Ume river are lower than in the southern two catchments $\left(\sim 7^{\circ} \mathrm{C}\right.$ mean annual and $\sim 0{ }^{\circ} \mathrm{C}$ mean winter, Table 1$)$. The low winter temperatures can be a driver for winter preservation of organic matter in the catchment, through lowering of metabolic rates during cold winter months and lower flow rates on rivers and through soils. Additionally, Haei et al. (2012) showed that bioavailability of DOM increased with increasing soil frost conditions in winter (i.e. lower winter temper- atures lead to more labile DOM release from soils); this was attributed not directly to lowered metabolism during the winter but rather frost-induced destruction of fine root structures and cell lysis releasing labile organic matter upon thawing. These processes combined effectively store reactive DOM in the catchment until the spring melt (June in Ume river), when warmer temperatures cause snow melt and large increases in soil water and consequently discharge in the catchment.

\subsection{Loadings of total organic carbon vs. labile organic carbon}

Loadings of DOC are often used to assess the impact of terrestrial DOM on marine systems (Asmala et al., 2012; Stedmon et al., 2011; Algesten et al., 2006). However, the bioavailability of DOM varies by orders of magnitude (del Giorgio and Davis, 2003), making it hard to predict how terrestrial DOM affects the receiving system. For the Baltic Sea, bacterial degradation of terrestrial DOM is estimated to consume in excess of one million tonnes of dissolved $\mathrm{O}_{2}$ annually (Helcom, 2004). Yet, little is known about the environmental and seasonal controls of DOM reactivity, which makes it hard to predict how DOM-driven $\mathrm{O}_{2}$ consumption and $\mathrm{CO}_{2}$ release will respond to environmental change. Generally, loadings of DOC in the studied rivers are driven by river flow, with the exception of May and June in Ume river, where the lower forested areas experience a spring flood with high DOC the month before the highest flow on the entire river, leading to higher loadings a month earlier than peak flow. While BOD loadings are influenced by flow, the general pattern followed by DOC is not seen in the BOD loadings, except in Lyckeby catchment, where the flow regime was extremely low in the summer months. In the other two rivers, the BOD loading regime was more complicated than DOC. In Ume river the difference between DOC and BOD is most striking in how the vast majority of BOD loading occurs in June, and while there is an increase in DOC loading in the fall, the BOD does not experience the same increase. 
The difference in absolute reactivity especially in the northern catchment means that reactivity loadings can differ considerably from the DOC loadings. Thus it is important to consider the reactivity loadings when examining the present and future impact of DOM on coastal systems.

In Ume river, the winter storage and flushing of reactive DOM during the spring flood is further supported by the loadings of BOD over the year. Looking at the loadings for the two spring flood months (May and June for the lower and upper parts of Ume river catchment respectively), it can be seen that almost $40 \%$ of the annual DOC loading and roughly $50 \%$ of the total BOD loading to the northern Baltic occurs at that time, while the rest of the months are relatively insignificant. This striking pattern is driven by the large spring flood on the river, but also by increasing DOC and bioavailability at that time (i.e. synchronicity of these two organic matter characteristics and flow). This large pulse of organic matter into the northern Baltic (i.e. Bothnian Sea) occurs at a time when the coastal waters are also beginning to warm, meaning that the microbial community in the coastal Bothnian Sea is able to take advantage of this, potentially shifting to a heterotrophic system. Indeed, the increasing freshwater input to the northern Baltic Sea has been shown to shift the ecosystem to net heterotrophy (Wikner and Andersson, 2012). Many coastal systems and estuaries are heterotrophic in nature, on a seasonal level (Cai, 2011), and this appears to be the case in the Bothnian Sea as well (Algesten et al., 2004), likely due to such a large pulse of labile material in a short period of time.

Loadings of DOM (both DOC and BOD) are driven largely by flow in Lyckeby river, which experienced a dry summer and moderate precipitation in the winter. Similarly, but less extreme than in Ume river, Lyckeby river experiences nearly $40 \%$ of BOD loading to the Baltic proper during the high flow month of January, with no other month providing more than $20 \%$ of the year's loading. While the mean annual temperature here is above $0^{\circ} \mathrm{C}$, January remains one of the coldest months of the year (mean winter temperature $0.17^{\circ} \mathrm{C}$ ), and as such, microbial activity in the coastal ocean is likely to be slower, leading to slow processing of the labile fraction of organic matter when it does reach the Baltic proper and consequently export of labile organic matter further out from the coastal zone. If labile organic matter is microbially processed at a slower rate during the large pulse in January, then it is less likely for this DOM to change the tendency of the Baltic proper from autotrophy, than it is in the more northern Bothnian Sea.

The Emån catchment, which experienced an anomalous flooding event in July, shows less variability in the loadings over the year than either of the two other rivers, and while the loadings of DOC are driven by flow, the loadings of BOD are more evenly distributed across the months. In fact, no one month delivers more than $25 \%$ of the total DOC and no month delivers more than $20 \%$ of the total BOD for the year.

\subsection{Climate and future loadings}

In the future, northern Europe and especially Scandinavia is expected to experience warmer and wetter weather. Sweden is predicted to see a large increase in rainfall (on the order of $21 \%$ year round) and warmer winters (Meier, 2006). While all three catchments are expected to experience an increase in precipitation year round, the seasonal pattern of this precipitation is expected to differ between the northern catchment and the southern catchments. In Ume river, the increase in precipitation is expected to be similar year round, while in the southern two catchments, the increase in precipitation is expected to be twice as high in the winter and spring months as during the rest of the year (Swedish Meteorological and Hydrological Institute Climate Predictions, http://www.smhi. se/klimatdata/klimatscenarier/Framtidens-klimat). In Emån catchment, the anomalous precipitation event in July, which led to widespread flooding in the catchment and an increase in flow on the river for that month effectively "flattened" the hydrograph for that year. This was in stark contrast to the other southern river system, Lyckeby, which experienced very little precipitation in the summer months and a more typical hydrograph dominated by winter precipitation. Future scenarios in this region suggest that the typical hydrograph will retain the general shape of the Lyckeby hydrograph, but with more extreme flow in winter and spring rather than just winter. The strong increase in flow will span a longer seasonal extent than currently seen and this could lead to a more "flattened" hydrographic shape in general. There are also indications that extreme flooding events will become more common in the future, and that the total excursion from mean flow will be greater. If increased precipitation and extreme events are to be expected in this region, it is likely that the delivery of both DOC and especially BOD will also become more constant throughout the year, as seen in the relatively steady loadings of BOD from Emån catchment over this year. Additionally, Weyhenmeyer et al. (2012), found that increased precipitation leads to lower water residence times in the catchment, and lowered the decay of organic carbon on its transit to the sea. If so, there is potential for the net delivery of DOC and BOD to be higher at river mouths in the future, in addition to more steady loadings year-round. Increased loadings and more even patterns of organic matter input into the Baltic Sea in the future are likely to increase the oxygen stress on the environment. Over the past 100 years, hypoxic and anoxic conditions in the Baltic Sea have been increasing both in the coastal zone and the open regions (Carstensen et al., 2014; Conley et al., 2011). Though inputs of nitrogen and phosphorus based nutrients have been regulated throughout much of the region, the increased and more constant input of DOC (and BOD) from rivers has the potential to counteract these reductions (Carstensen et al., 2014), and contribute to increasing hypoxic conditions in the Baltic Sea in the future. 
In the north, where the preservation of organic matter through the winter months helps to create a large springtime pulse of BOD to the Bothnian Sea, warming winters and increased precipitation across all seasons are likely to have a more drastic effect on catchment dynamics than in the south. Warmer mean winter temperatures, and reduced frost depth and duration (Haei et al., 2012) will lessen the preservation effect that is currently seen in the north. As the mean annual temperatures rise and become more like the southern catchments, it is likely that the overall reactivity of organic matter from the catchment will be lowered as well. The more constant input of labile organic matter may increase heterotrophy in the system year-round, compounding the freshwater discharge driven shift to heterotrophy already seen in this region (Wikner and Andersson, 2012).

\section{Conclusions}

Examining the biological reactivity of DOM and loadings of this reactive material from rivers offers insight into how seasonal and geographical characteristics of the terrestrial system can affect the marine ecosystem. The southern two catchments, while delivering similar amounts of DOC and BOD annually to the Baltic Sea, show drastically different patterns of loadings throughout the year, illustrating the importance of local hydrography and episodic precipitation events on the DOM dynamics in catchments. The northern catchment, with its colder winters, shows the influence of organic matter preservation and a strong spring flood on the DOC in northern rivers. The two-part spring flood due to melt in lower and higher altitudes of the catchment shows that peaks in DOC loading and BOD loading do not necessarily occur at the same time, underlining the importance of examining the reactivity of DOC to truly understand the influence of the terrestrial system on marine environments. The higher delivery of reactive material to the Bothnian Sea suggests that this region is highly influenced by the terrestrial system. With climate change leading to increased precipitation and warmer winter conditions in the north, the dominance of the strong spring peak of DOM delivery in Ume may give way to less intense seasonal patterns and lower overall reactivity delivery to the Bothnian Sea. Similarly, the seasonal changes in precipitation patterns expected in the southern catchments suggest that the dominance of winter delivery of reactive DOM to the Baltic proper from rivers like Lyckeby is likely to shift towards more even patterns of DOM loading to the Baltic such as seen in Emån catchment. In the future an understanding of both the reactivity of organic matter as well as flow patterns will be necessary to understand the effect of terrestrial organic matter inputs on marine systems.

Acknowledgements. The authors would like to thank Ana BedmarVillanueva, Sara Ekström and Raquel Vaquer-Sunyer for their help with sampling. The authors would also like to thank the two anonymous reviewers and the editor whose constructive comments helped to improve this paper. This work was supported by the Swedish Research Council (VR, no. 2010-4081; granted to E. Kritzberg) and was part of the Managing Multiple Stressors in the Baltic Sea project, FORMAS grant number 217-2010-126.

Edited by: B. A. Bergamaschi

\section{References}

Algesten, G., Wikner, J., Sobek, S., Tranvik, L. J., and Jansson, M.: Seasonal variation of $\mathrm{CO} 2$ saturation in the Gulf of Bothnia: Indications of marine net heterotrophy, Global Biogeochem. Cy., 18, GB4021, doi:10.1029/2004GB002232, 2004.

Algesten, G., Brydsten, L., Jonsson, P., Kortelainen, P., Löfgren, S., Rahm, L., Räike, A., Sobek, S., Tranvik, L., and Wikner, J.: Organic carbon budget for the Gulf of Bothnia, J. Marine Syst., 63, 155-161, 2006.

Alling, V., Humborg, C., and Morth, C. M.: Tracing terrestrial organic matter by delta S-34 and delta C-13 signatures in an Arctic and a subarctic estuary, Geochim. Cosmochim. Ac., 73, A29A29, 2009.

Amon, R. M. W. and Benner, R.: Rapid-Cycling of High-MolecularWeight Dissolved Organic-Matter in the Ocean, Nature, 369, 549-552, doi:10.1038/369549a0, 1994.

Amon, R. M. W. and Benner, R.: Bacterial utilization of different size classes of dissolved organic matter, Limnol. Oceanogr., 41, 41-51, 1996.

Asmala, E., Stedmon, C. A., and Thomas, D. N.: Linking CDOM spectral absorption to dissolved organic carbon concentrations and loadings in boreal estuaries, Estuar. Coast. Shelf S., 111, 107-117, doi:10.1016/J.Ecss.2012.06.015, 2012.

Asmala, E., Autio, R., Kaartokallio, H., Pitkänen, L., Stedmon, C. A., and Thomas, D. N.: Bioavailability of riverine dissolved organic matter in three Baltic Sea estuaries and the effect of catchment land use, Biogeosciences, 10, 6969-6986, doi:10.5194/bg-10-6969-2013, 2013.

Battin, T. J., Luyssaert, S., Kaplan, L. A., Aufdenkampe, A. K., Richter, A., and Tranvik, L. J.: The boundless carbon cycle, Nature Geosci., 2, 598-600, doi:10.1038/Ngeo618, 2009.

Berggren, M., Lapierre, J. F., and del Giorgio, P. A.: Magnitude and regulation of bacterioplankton respiratory quotient across freshwater environmental gradients, ISME Journal, 6, 984-993, doi:10.1038/Ismej.2011.157, 2012.

Bishop, K. H., Lundström, U. S., and Giesler, R.: Transfer of organic $\mathrm{C}$ from forest soils to surface waters: example from northern Sweden, Appl. Geochem., 8, Supplement 2, 11-15, doi:10.1016/S0883-2927(09)80003-6, 1993.

Cai, W. J.: Estuarine and coastal ocean carbon paradox: $\mathrm{CO}_{2}$ sinks or sites of terrestrial carbon incineration?, Annual Review of Marine Science, 3, 123-145, doi:10.1146/annurev-marine-120709142723, 2011.

Carstensen, J., Andersen, J. H., Gustafsson, B. G., and Conley, D. J.: Deoxygenation of the Baltic Sea during the last century, P. Natl. Acad. Sci. USA, 111, 5628-5633, doi:10.1073/pnas.1323156111, 2014.

Cole, J. J., Prairie, Y. T., Caraco, N. F., McDowell, W. H., Tranvik, L. J., Striegl, R. G., Duarte, C. M., Kortelainen, P., Downing, J. A., Middelburg, J. J., and Melack, J.: Plumbing the global 
carbon cycle: Integrating inland waters into the terrestrial carbon budget, Ecosystems, 10, 171-184, doi:10.1007/S10021-0069013-8, 2007.

Conley, D. J., Carstensen, J., Aigars, J., Axe, P., Bonsdorff, E., Eremina, T., Haahti, B. M., Humborg, C., Jonsson, P., Kotta, J., Lannegren, C., Larsson, U., Maximov, A., Medina, M. R., Lysiak-Pastuszak, E., Remeikaite-Nikiene, N., Walve, J., Wilhelms, S., and Zillen, L.: Hypoxia Is Increasing in the Coastal Zone of the Baltic Sea, Environ. Sci. Technol., 45, 6777-6783, doi:10.1021/Es201212r, 2011.

Dagg, M., Sato, R., Liu, H. B., Bianchi, T. S., Green, R., and Powell, R.: Microbial food web contributions to bottom water hypoxia in the northern Gulf of Mexico, Cont. Shelf Res., 28, 1127-1137, doi:10.1016/J.Csr.2008.02.013, 2008.

del Giorgio, P. A. and Davis, J.: Patterns in Dissolved Organic Matter Lability and Consumption Across Aquatic Ecosystems, in: Aquatic Ecosystems: Interactivity of Dissolved Organic Matter, edited by: Findlay, S. and Sinsabaugh, R. L., Academic Press, San Diego, CA, 399-425, 2003.

Deutsch, B., Alling, V., Humborg, C., Korth, F., and Mörth, C. M.: Tracing inputs of terrestrial high molecular weight dissolved organic matter within the Baltic Sea ecosystem, Biogeosciences, 9, 4465-4475, doi:10.5194/bg-9-4465-2012, 2012.

De Wit, H. A., Mulder, J., Hindar, A., and Hole, L.: Long-term increase in dissolved organic carbon in streamwaters in Norway is response to reduced acid deposition, Environ. Sci. Technol., 41, 7706-7713, doi:10.1021/Es070557f, 2007.

Erlandsson, M., Buffam, I., Folster, J., Laudon, H., Temnerud, J., Weyhenmeyer, G. A., and Bishop, K.: Thirty-five years of synchrony in the organic matter concentrations of Swedish rivers explained by variation in flow and sulphate, Glob. Change Biol., 14, 1191-1198, doi:10.1111/j.1365-2486.2008.01551.x, 2008.

Evans, C. D.: Modelling the effects of climate change on an acidic upland stream, Biogeochemistry, 74, 21-46, doi:10.1007/S10533-004-0154-6, 2005.

Evans, C. D., Jones, T. G., Burden, A., Ostle, N., Zielinski, P., Cooper, M. D. A., Peacock, M., Clark, J. M., Oulehle, F., Cooper, D., and Freeman, C.: Acidity controls on dissolved organic carbon mobility in organic soils, Glob. Change Biol., 18, 33173331, doi:10.1111/j.1365-2486.2012.02794.x, 2012.

Garnett, M. H., Ineson, P., and Stevenson, A. C.: Effects of burning and grazing on carbon sequestration in a Pennine blanket bog, UK, Holocene, 10, 729-736, doi:10.1191/09596830094971, 2000.

GSD Survey map, open GIS database, available at: http://www. lantmateriet.se, last access: 16 June 2013.

Haei, M., Öquist, M. G., Ilstedt, U., and Laudon, H.: The influence of soil frost on the quality of dissolved organic carbon in a boreal forest soil: combining field and laboratory experiments, Biogeochemistry, 107, 95-106, 2012.

Helcom: The fourth Baltic Sea pollution load compilation (PLC-4), Helsinki Commission, Helsinki, Finland, 2004.

Helms, J. R., Stubbins, A., Ritchie, J. 'D., Minor, E. C., Kieber, D. J., and Mopper, K.: Absorption spectral slopes and slope ratios as indicators of molecular weight, source, and photobleaching of chromophoric dissolved organic matter, Limnol. Oceanogr., 53, 955-969, 2008.

Hruška, J., Krám, P., Mcdowell, W. H., and Oulehle, F.: Increased Dissolved Organic Carbon (DOC) in Central European Streams is Driven by Reductions in Ionic Strength Rather than Climate Change or Decreasing Acidity, Environ. Sci. Technol., 43, 43204326, doi:10.1021/es803645w, 2009.

Jollymore, A., Johnson, M. S., and Hawthorne, I.: Submersible UVVis Spectroscopy for Quantifying Streamwater Organic Carbon Dynamics: Implementation and Challenges before and after Forest Harvest in a Headwater Stream, Sensors, 12, 3798-3813, 2012.

Koehler, B., von Wachenfeldt, E., Kothawala, D., and Tranvik, L. J.: Reactivity continuum of dissolved organic carbon decomposition in lake water, J. Geophys. Res., 117, G01024, doi:10.1029/2011JG001793, 2012.

Kritzberg, E. S. and Ekström, S. M.: Increasing iron concentrations in surface waters - a factor behind brownification?, Biogeosciences, 9, 1465-1478, doi:10.5194/bg-9-1465-2012, 2012.

Laudon, H., Taberman, I., Ågren, A., Futter, M., OttossonLöfvenius, M., and Bishop, K.: The Krycklan Catchment Study - A flagship infrastructure for hydrology, biogeochemistry, and climate research in the boreal landscape, Water Resour. Res., 47, 7154-7158, doi:10.1002/wrcr.20520, 2013.

Meier, H. E. M.: Baltic Sea climate in the late twenty-first century: a dynamical downscaling approach using two global models and two emission scenarios, Clim. Dynam., 27, 39-68, doi:10.1007/s00382-006-0124-x, 2006.

Miller, W. L., Moran, M. A., Sheldon, W. M., Zepp, R. G., and Opsahl, S.: Determination of apparent quantum yield spectra for the formation of biologically labile photoproducts, Limnol. Oceanogr., 47, 343-352, 2002.

Monteith, D. T., Stoddard, J. L., Evans, C. D., de Wit, H. A., Forsius, M., Hogasen, T., Wilander, A., Skjelkvale, B. L., Jeffries, D. S., Vuorenmaa, J., Keller, B., Kopacek, J., and Vesely, J.: Dissolved organic carbon trends resulting from changes in atmospheric deposition chemistry, Nature, 450, 537-539, doi:10.1038/Nature06316, 2007.

Nagata, T.: Organic matter-bacteria interactions in seawater, in: Microbial ecology of the oceans, 2nd Edn., edited by: Kirchman, D. L., John Wiley and Sons, 207-241, 2008.

Oni, S. K., Futter, M. N., Bishop, K., Köhler, S. J., OttossonLöfvenius, M., and Laudon, H.: Long-term patterns in dissolved organic carbon, major elements and trace metals in boreal headwater catchments: trends, mechanisms and heterogeneity, Biogeosciences, 10, 2315-2330, doi:10.5194/bg-10-2315-2013, 2013.

Perdue, E. M.: Chemical composition, structure, and metal binding properties, in: Aquatic humic substances: ecology and biogeochemistry, edited by: Hessen, D. O. and Tranvik, L. J., Springer, 41-61, 1998.

Pomeroy, L. R.: Oceans food web, a changing paradigm, Bioscience, 24, 499-504, 1974.

Reader, H. E. and Miller, W. L.: The efficiency and spectral photon dose dependence of photochemically induced changes to the bioavailability of dissolved organic carbon, Limnol. Oceanogr., 59, 182-194, doi:10.4319/lo.2014.59.1.0182, 2014.

Rolff, C. and Elmgren, R.: Use of riverine organic matter in plankton food webs of the Baltic Sea, Mar. Ecol.-Prog. Ser., 197, 81101, doi:10.3354/Meps197081, 2000.

Rydin, E., Vrede, T., Persson, J., Holmgren, S., Jansson, M., Tranvik, L., and Milbrink, G.: Compensatory nutrient enrichment in an oligotrophicated mountain reservoir - effects and fate of 
added nutrients, Aquat. Sci., 70, 323-336, doi:10.1007/s00027008-8061-x, 2008.

Statistics Sweden, available at: http://www.scb.se, last access: 16 June 2014.

Stedmon, C. A., Amon, R. M. W., Rinehart, A. J., and Walker, S. A.: The supply and characteristics of colored dissolved organic matter (CDOM) in the Arctic Ocean: Pan Arctic trends and differences, Mar. Chem., 124, 108-118, doi:10.1016/J.Marchem.2010.12.007, 2011.

Strohmeier, S., Knorr, K.-H., Reichert, M., Frei, S., Fleckenstein, J. H., Peiffer, S., and Matzner, E.: Concentrations and fluxes of dissolved organic carbon in runoff from a forested catchment: insights from high frequency measurements, Biogeosciences, 10, 905-916, doi:10.5194/bg-10-905-2013, 2013.

Swedish Meteorological and Hydrological Institute: Climate Data, available at: http://www.smhi.se/klimatdata, last access: 16 June 2014.

Swedish Meteorological and Hydrological Institute: Climate Predictions, available at: http://www.smhi.se/klimatdata/ klimatscenarier/Framtidens-klimat, last access: 16 June 2014.

Swedish Meteorological and Hydrological Institute's Vattenweb, available at: http://vattenweb.smhi.se/station/, last access: 16 June 2014.
Tranvik, L. J., Downing, J. A., Cotner, J. B., Loiselle, S. A., Striegl, R. G., Ballatore, T. J., Dillon, P., Finlay, K., Fortino, K., Knoll, L. B., Kortelainen, P. L., Kutser, T., Larsen, S., Laurion, I., Leech, D. M., McCallister, S. L., McKnight, D. M., Melack, J. M., Overholt, E., Porter, J. A., Prairie, Y., Renwick, W. H., Roland, F., Sherman, B. S., Schindler, D. W., Sobek, S., Tremblay, A., Vanni, M. J., Verschoor, A. M., von Wachenfeldt, E., and Weyhenmeyer, G. A.: Lakes and reservoirs as regulators of carbon cycling and climate, Limnol. Oceanogr., 54, 2298-2314, doi:10.4319/Lo.2009.54.6_Part_2.2298, 2009.

Weishaar, J. L., Aiken, G. R., Bergamaschi, B. A., Fram, M. S., Fujii, R., and Mopper, K.: Evaluation of specific ultraviolet absorbance as an indicator of the chemical composition and reactivity of dissolved organic carbon, Environ. Sci. Technol., 37, 47024708, doi:10.1021/es030360x, 2003.

Weyhenmeyer, G. A., Froberg, M., Karltun, E., Khalili, M., Kothawala, D., Temnerud, J., and Tranvik, L. J.: Selective decay of terrestrial organic carbon during transport from land to sea, Glob. Change Biol., 18, 349-355, doi:10.1111/J.13652486.2011.02544.X, 2012.

Wikner, J. and Andersson, A.: Increased freshwater discharge shifts the trophic balance in the coastal zone of the northern Baltic Sea, Glob. Change Biol., 18, 2509-2519, doi:10.1111/j.13652486.2011.02544.x, 2012. 